\title{
Memorial para promoção a professor titular da Universidade Federal Fluminense
}

JORGE NASSIM VIEIRA NAJJAR

O inferno dos vivos não é algo que será: se existe, é aquele que já está aqui, o inferno no qual vivemos todos os dias, que formamos estando juntos. Existem duas maneiras de não sofrer. A primeira é fácil para a maioria das pessoas: aceitar o inferno e tornar-se parte deste até o ponto de deixar de percebê-lo. A segunda é arriscada e exige atenção e aprendizagem contínuas: tentar saber reconhecer quem e o que, no meio do inferno, não é inferno, e preservá-lo, e abrir espaço. (Ítalo Calvino. As cidades invisiveis)
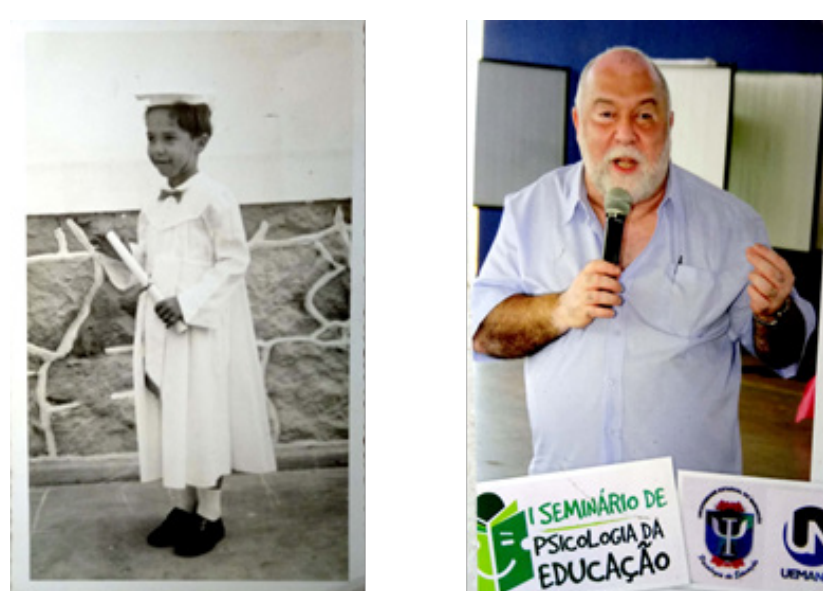

Ter a oportunidade de me tornar Professor Titular na Universidade em que me formei e a qual tenho extremo apreço é algo muito maior do que pude sonhar no início de minha carreira acadêmica. Mesmo a legislação tendo se modificado ${ }^{1}$, fazendo com que a posição de Professor Titular faça parte da carreira do magistério superior, chegar ao ápice da carreira universitária é uma realização ímpar.

A elaboração de um memorial que dê conta de toda a minha carreira acadêmica é tarefa obrigatória no processo de pleitear o título. No início de sua elaboração achei que seria uma tarefa meramente burocrática/administrativa mas, ao longo do processo, fui me dando conta o quanto este fazer ajuda a estruturação do Plano de Carreira e Cargos do Magistério Federal, criado critérios para a ascensão profissional nas universidades federais e prevendo a autonomia para cada universidade federal criar os mecanismos para o acesso ao cargo de professor titular". (SILVA, 2016, p. 61 - 62) 
repensar criticamente minha trajetória acadêmica e, com isto, retomar uma série de memórias que ajudam a construir minha identidade como professor e como intelectual.

Poderia, pelas regras estabelecidas, ter realizado concurso para professor titular no ano passado. Teria sido ideal, pois em 2019 uma série de acontecimentos importantes marcaram minha vida. Foi neste ano que fiz 60 anos de idade. Foi nele também que completei 25 anos como professor da UFF e 15 anos como Doutor em Educação. Entretanto, 2019 foi também o ano em que tomei consciência de algo que seria óbvio, mas que só em situações limite nos damos conta. Sou finito, isto é, não tenho domínio sobre o meu futuro e muito pouco sobre o meu presente. A descoberta de um câncer mudou não só a minha percepção de vida como, praticamente, modificou meu cotidiano ao ponto de eu só conseguir dar conta das tarefas para o concurso de professor titular quase um ano depois do período em que inicialmente pensei em fazê-lo.

Não quero nem devo adiar mais a tarefa. Primeiro, porque quero muito ser professor titular. É algo que vem coroar uma trajetória da qual tenho muito orgulho. Segundo, mas não menos importante, estamos vivendo um período - o Brasil, a Universidade e o funcionalismo público brasileiro - que se caracteriza pela perda de uma série de direitos sociais e trabalhistas conquistados ao longo dos anos. Um destes é o direito à promoção na carreira docente, que está sendo colocado em xeque por Proposta de Emenda Constitucional apresentada pelo governo federal, dentro de um conjunto de políticas de direita de cunho neoliberal e conservador ${ }^{2}$.

Silva (2016) mostra que

O memorial acadêmico apresenta uma dimensão subjetiva que transcende a linguagem dos documentos burocráticos e seus discursos formalizados, de maneira asséptica, cientificamente ponderada e tecnicamente equilibrada, os quais caracterizam a escrita de viés administrativo, ao incorporar uma dimensão narrativa na qual o sujeito tem maior centralidade. (SILVA, 2016, p. 57)

O presente memorial, tal como tem sido praxe atualmente na universidade brasileira, organiza-se, em grande medida, desta forma, até mesmo porque junto com ele tenho por obrigação apresentar um Dossiê descritivo das principais atividades acadêmicas que realizei em minha trajetória, não tendo sentido repetir esta forma descritiva no Memorial. Assim, me dei ao direito de fazer algo que muitas vezes critico em meus orientandos, que é a tendência de explicar os

$2 \quad$ Algumas dessas medidas são apontadas por Dourado (2019). 
fenômenos a partir de suas origens mais distantes, quase "arqueológicas". Como poderão ver, começo a apresentar a minha história desde a minha origem familiar e do começo da minha escolarização.

Vale destacar que grande parte da minha trajetória se passa como professor da UFF. Nela fiz minha Graduação e meu Mestrado. Minha trajetória está, nesta medida, absolutamente enredada com a própria trajetória desta Universidade, nascida no início dos anos 1960 e, portanto, mais jovem do que eu.

Lembro que, comecei meu mestrado no prédio onde atualmente se localiza a Faculdade de Enfermagem e que logo no primeiro ano de curso veio a determinação de nos mudarmos para o Campus do Gragoatá, recém inaugurado. Visitando este campus, eu e alguns colegas nos colocamos contra a mudança, tendo como uma das principais justificativas a aridez que lhe era peculiar. Não havia árvores, só pequenos arbustos que não nos protegiam do sol inclemente de Niterói. A mudança aconteceu independentemente de nossos argumentos contrários.

Recentemente, caminhando pelo campus, tive uma epifania ao admirar as frondosas árvores que se espalham por todo o lugar. Acompanhei o crescimento, e cresci junto com cada uma delas. Os pequenos arbustos transformaram-se em árvores repletas de verde, sombras, pássaros e saguis. Constatar tal coisa foi, assim, constatar o quanto me modifiquei ao longo dos anos a partir da minha interação com esta universidade. Sou o que sou hoje pelo contato estreito com meus alunos de graduação e pós-graduação e com meus colegas no trabalho docente e administrativo. Nestes muitos anos de UFF, infelizmente, me construí professor a partir das memórias daqueles amigos que já se foram, como os professores Sueli Camargo, companheira diária de lutas por uma educação de qualidade, e Dácio Lobo Jr., colega desde o mestrado, cuja trajetória na universidade foi muito semelhante à minha.

Elaborar esta Memorial foi fundamental para me dar conta, sem falsa modéstia, do quanto já realizei e quantas coisa interessantes fiz em minha trajetória acadêmica. Claro que este trabalho, além da explicitação de muitos acontecimentos, traz também omissões, esquecimentos e incorreções. Trabalhar com a memória é assim.

$\mathrm{Na}$ sociedade contemporânea, a autonarrativa carrega em si, como processo de subjetivação, dimensões identitárias, públicas, explícitas, instantâneas, personalistas, factuais, relacionais e midiáticas, que oferecem o privado, o íntimo e o confessional em distintos níveis, mas que sempre apresentam uma orientação alterdirigida, ou seja, construções de si orientadas para uma exposição que objetiva legitimar formas de ser e estar no mundo. (SILVA, 2016, p. 46) 
Tanto quanto as lembranças que trago à tona, estes esquecimentos e omissões vão constituindo a minha identidade como professor universitário.

\section{CHEGANDO NA ESCOLA}

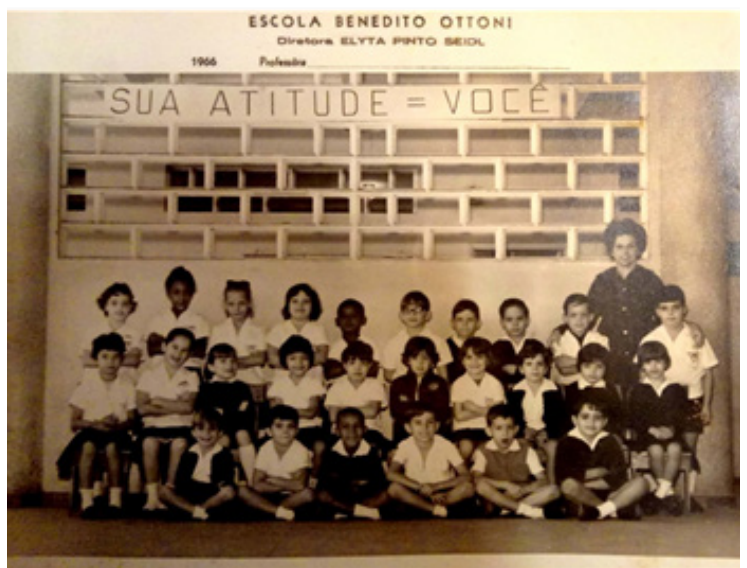

\section{- Quem aqui é Jorge Najjar?}

Foi assim no meu primeiro dia na escola primária. Uma senhora entrou na sala de aula onde eu tinha acabado de chegar, chamando pelo meu nome. Não era a professora, pois esta já havia nos recebido quando chegamos. Era uma estranha, da qual só me lembro nesta ocasião. Tinha seis para sete anos e era absurdamente tímido, o que tornou a situação de levantar o braço, me identificando na frente de todos, me levantar e me retirar da sala com ela, levando todo meu material escolar, um pesadelo.

Já havia frequentado uma escola antes. Bem na frente da vila onde morava, próxima à Praça da Bandeira, havia duas escolas, ambas públicas: Bárbara Ottoni e Benedito Ottoni ${ }^{3}$. A primeira era um Jardim de Infância e a segunda uma escola primária ${ }^{4}$. Minha primeira experiência com a escolarização aconteceu no Jardim de Infância, mas dela praticamente não me recordo de nada. Foi na escola pública Benedito Ottoni que comecei, de fato, a aprender o que é escola. um outro erguido no mesmo terreno e a escola reinaugurada em agosto de 1964 pelo então governador Carlos Lacerda.

4 Esta nomenclatura das etapas da educação no Brasil é referente ao disposto na Lei 4.024/61, nossa primeira Lei de Diretrizes e Bases da Educação Nacional (LDB), vigente à época. De agora em diante, para evitar confusões, no presente texto usarei a nomenclatura apontada pela Lei 9.394/96, a LDB em vigor. 
Sou filho de uma família de classe média baixa, moradora, então, da grande Tijuca. Minha mãe era professora primária, tendo feito seu curso de normalista no Instituto de Educação do Rio de Janeiro, situado próximo a nossa casa. Mas nunca vi minha mãe lecionando, pois logo que casou e tornou-se mãe, largou o magistério e se dedicou exclusivamente ao lar. Pelo que soube, o abando da profissão docente foi, em muito, influenciado pela postura de meu pai.

Moramos, desde o casamento de meus pais, juntos com meus avós maternos. Assim, sempre tive uma família ampliada e meus avós foram decisivos para minha formação. Meu avô era bombeiro e, tendo entrado na corporação como soldado, chegou a ser tenente coronel. Tinha uma letra linda, que era seu orgulho, mas possuía pouca escolarização. Minha avó, por sua vez, casou-se com meu avô quando tinha quatorze anos e sempre foi "dona de casa". Lia e escrevia com dificuldade e pouco se importava com isto, pois as senhoras com quem ela convivia possuíam pouquíssima ou nenhuma escolarização. Lembremos que na passagem do século XIX para o século XX, 80\% da população brasileira era analfabeta e mesmo na metade do século XX, em 1950, somente 3 em cada 10 crianças em idade escolar ingressavam na escola na cidade do Rio de Janeiro, então capital da República e uma das cidades mais desenvolvidas no país (NAJJAR, 2015).

Meu pai, oriundo de uma muito pequena cidade do norte do Líbano, chegou ao Brasil em 1951, com dezenove anos de idade, sem saber uma palavra de português. Seu pai penhorou o sítio que dava sustento à família e deu o montante a ele, com a condição que ele enviasse regularmente o dinheiro necessário para pagar o penhor. Como o plano de meu pai era emigrar para a Austrália, ele estava aprendendo inglês. Entretanto, um pouco antes do período previsto para a viagem, a Austrália fechou suas fronteiras para os imigrantes árabes, e meu pai teve que mudar de planos, escolhendo o Brasil como destino. A ideia, como de muitos emigrantes libaneses dele conhecidos, era a de se mudar para um país que desse condições de trabalho, para ficar rico e retornar para o Líbano. Também, como muitos imigrantes árabes que aqui chegaram, na prática ele se estabeleceu no Brasil, constituiu família, teve quatro filhos, abriu um comércio de roupas, ganhou algum dinheiro (nunca ficou rico) e só retornou a seu país natal três vezes, por curtos períodos de tempo.

Meu pai morreu em 2003, tendo vivido grande parte da sua vida no Brasil (52 anos em 71 de vida), mas sempre foi visto aqui como "gringo", como "turco". Nas três vezes em que voltou ao Líbano, as pessoas estranhavam seu sotaque ao falar árabe e sua inadequação a diversos costumes. Falavam que ele estava muito brasileiro. Como muito migrantes, era um estrangeiro aqui, mas também um estrangeiro lá. 
Como já mencionei, ele chega no Brasil sem saber nada de português, mas com a obrigação de logo trabalhar e enviar dinheiro para seu pai, para que ele não perdesse a terra de onde tirava seu sustento. Assim, com a ajuda de amigos, comprou uma maleta e uma série de pequenos produtos com preços semelhantes. Munido disto, saía, de casa em casa na zona norte do Rio de Janeiro, oferecendo estes produtos. Tornou-se, assim, o "gringo da prestação". No início, só sabia como, em português, oferecer o produto ("vai querer, freguesa?"), o nome dos produtos e os preços. Mas aprendeu rápido, pois logo abandonou os lenços e meias e passou a vender, ainda de casa em casa, joias. Em poucos anos engrenou um relacionamento sério com uma jovem professora, filha de militar, e constituiu família.

Ao chegar no Brasil, meu pai só possuía, em termos de escolarização, o equivalente ao Ensino Fundamental. Tal como os outros membros da família, talvez com exceção de minha mãe, ele nunca se constituiu como modelo que me incentivasse na escola. Também nunca me ajudou em meus deveres de casa, nem tirou minhas dúvidas em qualquer disciplina. Para isso, só tenho lembranças de minha mãe. Entretanto, todos os quatro (pais e avós), foram fundamentais para o sucesso de minha escolarização.

Gonçalves (2015) aponta para diversas formas diferentes de relação entre família e escola. Ela pode ser referente a um único aluno ou a todos eles; pode ser formal ou informal; pode se realizar no âmbito doméstico ou no escolar etc. Seguindo esta perspectiva, ao rememorar a relação entre família e escola em minha própria história, tenho não só que identificar sua presença ou ausência, mas a forma como ela se constituiu.

Apesar de lembrar de minha mãe nas festas e nas reuniões de pais que aconteciam na escola, não foi esta relação mais formalizada que marca minhas memórias. Minha família foi fundamental para meu sucesso escolar por diversos outros motivos. Primeiro, pelo amor e segurança que sempre pude sentir no convívio familiar. Fui uma criança amada. Mesmo meu pai, que passava grande parte do dia trabalhando e que eu praticamente só convivia no início da manhã e nos fins de semana, marcou minha infância com seu carinho e aconchego. Quando fui à escola, sabia que minha família estava comigo e que se desse algo errado eu tinha para onde correr.

A segunda influência de minha família em meu processo de escolarização tem relação com o significado extremamente positivo que a escola tinha para ela. Mesmo em uma família com pouca escolarização, a escola era vista como algo importante. Desde cedo, nunca faltei aula por motivos fúteis, pois isto era impensável lá em casa. Lembro de dias em que fui à escola mesmo com pequena febre. Quanto aos deveres de casa, eles eram feitos logo após ao almoço (a escola 
era pela manhã), e nada, nenhuma brincadeira, descanso ou televisão existia antes que os deveres fossem concluídos. Desde pequeno aprendi a ter disciplina nos estudos.

Há um ditado árabe, que meu pai repetia inúmeras vezes, que reflete seu pensamento sobre a escola. Ele contava a história de um pai que apresentava seu filho aos professores e dizia: "estou lhes entregando meu filho com pele, carne e ossos. Me devolva com pele, ossos e um diploma". Tal ditado tinha uma dureza que não condizia com um pai que me abraçava sempre que podia, mas com certeza condizia com a mentalidade do imigrante que, com seu trabalho sistemático, construiu do zero sua vida no Brasil e que lia frequentemente dicionários para tentar falar melhor o português.

O terceiro motivo que me faz identificar a influência de minha família em meu processo de escolarização relaciona-se ao seu apoio material às minhas ações de acesso aos elementos culturais vistos como positivos pela escola. Não éramos uma família pobre, mas não possuíamos muitos recursos. Assim, nunca tivemos roupas de grife, nossos brinquedos eram simples e só eram comprados nas datas festivas, e quando amigos iam para minha casa, o lanche invariavelmente era pão com margarina e goiabada e um copo de groselha. Mas nunca se recusaram a comprar um livro, eu regularmente participava dos passeios culturais (pagos) da escola, ia sempre ao teatro e ao cinema.

Falando em livros, esta foi uma outra influência de minha família. Não exatamente de meus pais ou avós, que não liam nada nem tinham qualquer livro em casa que lhes pertencesse, mas de minhas tias. Se aprendi a ler na escola, aprendi a gostar de ler com duas tias, irmãs do meu avô, uma ex-freira e outra professora aposentada. Quando já frequentava a escola, ambas passaram, em meu aniversário e no Natal, a me presentear com livros de Monteiro Lobato. Meu primeiro livro, que reli umas cinco vezes e que marcou minha vida de leitor, foi Caçadas de Pedrinho. Identifiquei-me completamente com o mundo do Sítio do Pica-Pau Amarelo e esperava ansiosamente o tempo passar para ter em mãos um outro livro. Talvez um dos livros que mais tenha relido, de puro deleite, foi a versão de Lobato dos 12 Trabalhos de Hércules, no qual Pedrinho, Emília e o Visconde de Sabugosa ajudavam Hércules a completar com êxito sua saga. Identifiquei um processo semelhante com meus filhos (que detestaram Lobato por conta da linguagem, a eles estranha), o mais velho com Harry Potter e o mais novo com Capitão Cueca. Diferentes personagens e diferentes estilos, mas a mesma capacidade de tornar a leitura um hábito imprescindível para eles.

Há que se deixar claro que a relação entre escola e família é de grande complexidade e que não há uma receita ou fórmula mágica que faça com que o sucesso escolar seja resultado necessário. Note que éramos quatro irmãos (eu 
era o mais velho) e que um não terminou o ensino médio, outro não terminou o ensino superior e o terceiro, que cursou com sucesso duas faculdades, nunca teve uma vida escolar de destaque nem trabalhou nas profissões em que foi formado em nível superior. O que deu certo para mim, não necessariamente deu certo para eles.

Feita esta digressão sobre minha família, creio que necessária para entender o contexto de minha escolarização inicial, vale refletir sobre o acontecido no meu primeiro dia na escola no Ensino Fundamental. Tempos depois do acontecido, soube que quem articulou minha mudança de sala tinha sido a "Tia" ${ }^{5} \mathrm{Olga}$, professora da escola e prima distante de meu pai, que soube que eu estava estudando ali. Ela conseguiu minha transferência para a turma da Tia Vilma, professora que me alfabetizou. Ela era uma professora extremamente carinhosa e competente, e fez um excelente trabalho comigo e com toda turma. Lembro de poucos nomes de professores da educação básica, mas o dela eu nunca esqueci, pois sua marca sobre mim foi indelével. Provavelmente, se houvesse permanecido na turma original, minha alfabetização seria menos competente e minha trajetória acadêmica seria outra, mostrando que mesmo dentro de uma unidade escolar podem existir diferentes redes de escolarização ${ }^{6}$, com consequências significativas para o futuro dos alunos.

Mais do que Tia Vilma, a presença docente mais forte que tive no ensino fundamental foi a da Tia Olga. Ela foi minha professora por três anos seguidos, nos quais tive grande sucesso escolar (até ganhei da escola um gravadorzinho de rolo pelo meu desempenho em matemática). Ela, no tempo devido, criou em sua casa um grupo de reforço escolar para alguns alunos, que servia como preparatório para os exames de admissão para as escolas públicas vistas como de grande qualidade. Frequentei ativamente o grupo e, em função dele e da boa escolarização que tive, passei no concurso de diversas escolas: Instituto de Educação do Rio de Janeiro, Colégio Pedro II, Colégio Militar do Rio de Janeiro e Colégio de Aplicação da UERJ. Minha mãe, com sabedoria, escolheu o Colégio de Aplicação, e nele cursei o segundo segmento do ensino fundamental e todo o ensino médio. Vale destacar que, além de mim, dois outros colegas de escola e do grupo da Tia Olga passaram, para o CAP UERJ, uma das mais prestigiosas escolas do estado do Rio de Janeiro, possuidora de um dos concursos de acesso mais difíceis.

5 Apesar das pertinentes críticas ao uso do termo "tia" para identificar uma professora (ver, p. ex. FREIRE, 1997), utilizo-o neste trabalho pois ele marcou profundamente, e carinhosamente, as memórias sobre o início de minha escolarização.

6 Sobre a escola dualista, com diferentes redes de escolarização, ver Baudelot \& Establet (1971). 


\section{O COLÉGIO DE APLICAÇÃO DA UERJ}

Minha passagem pelo CAP UERJ condicionou muita coisa de minha vida acadêmica posterior, por vários motivos. Sempre tinha sido um aluno de destaque, mas ali, fruto da dificuldade do concurso de acesso, todos eram alunos de destaque, que teriam sucesso em qualquer outra escola. Diferentemente das escolas estaduais regulares, já havia uma seleção prévia que trazia para dentro do Colégio de Aplicação alunos que, em grande medida compartilhavam o arbitrário cultural $^{7}$ apreciado pela escola. Assim, passei sete anos de minha vida convivendo com colegas que falavam o português visto como correto, que tinham hábitos de leitura, certa disciplina para os estudos e, mais do que tudo, de forma certamente elitista cultivavam um ethos, vivamente incentivados pela escola, de que "eram os melhores" e que o futuro acadêmico e profissional estava completamente aberto para eles. A sensação era a de que bastava querer e se dedicar um pouco que você poderia ser qualquer coisa. Fazer faculdade parecia ser o óbvio. As questões eram qual instituição universitária escolher e que profissão abraçar.

Outro motivo que certamente influenciou para que minha passagem pelo Colégio de Aplicação fosse tão marcante foi o fato dela se organizar em regime de tempo integral. Estudava todos os dias de manhãzinha até quatro ou cinco horas da tarde, menos às quartas-feiras de tarde, que era dia de reunião de planejamento dos professores. O CAP UERJ era uma escola conteudista. Assim, grande parte do meu tempo escolar se passava em sala de aula, aprendendo as disciplinas regulares. Entretanto, mesmo com essa perspectiva, havia tempo para muito mais. Por exemplo, havia tempo para esportes. Fiz atletismo nos tempos vagos e participava ativamente da equipe da escola. Isto era incentivado pela olimpíada que tínhamos todos os anos e na qual todos os alunos participavam de competições esportivas, divididos em quatro equipes de cores diferentes. Havia o coral, as artes plásticas e outras atividades além do currículo regular. Isto me permitiu uma formação mais holística do que normalmente é propiciada aos alunos de escola de tempo parcial.

Junte-se a isso a camaradagem construída pelo convívio regular com meus colegas de turma. A própria forma como se organizava a estrutura física da sala de aula levava à integração entre nós. Nunca estudei em carteiras separadas dispostas em fila, mas sempre ao redor de mesas que reuniam seis estudantes e que levavam a uma interlocução permanente entre nós. 
Mas talvez a vivência mais importante no CAP tenha ocorrido nos últimos anos do ensino médio, a partir de um contato mais estreito com a cultura e com a política. Formamos um grupo de teatro que nos uniu em torno de uma discussão, que era ao mesmo tempo artística e política. Fazíamos nossas próprias peças e elas, comumente, recaíam sobre questões sociais. Vale lembrar que ainda estávamos no período da ditadura civil-militar e isto fez com que vários de nós sofressem advertências da direção escolar. Nosso grupo de teatro se juntou a diversos grupos de escolas secundárias do Rio de Janeiro e criamos uma mostra anual de teatro. Tal contato com outras escolas, várias possuidoras de grêmios, fez com que incrementássemos a política estudantil no âmbito da nossa própria escola. O contato com os partidos políticos de esquerda, então na clandestinidade, foi decorrência natural deste processo de politização.

Minha vivência no teatro fez com que eu modificasse de forma acentuada meu projeto de futuro. Sempre tive o sonho de ser um "cientista", de forma muito genérica. Era bom em matemática, mas flertei com a biologia e a perspectiva era de ser um médico dedicado à pesquisa ou algo assim. Entretanto, na hora do vestibular optei por fazer a faculdade de teatro na Universidade Federal do Estado do Rio de Janeiro - UNIRIO, para desgosto da minha família, embora dela não tivesse qualquer tipo de punição ou censura à efetivação desta escolha profissional. Cursei a faculdade de teatro por dois anos. Descobri ao longo do tempo que não era aquilo que eu queria em termos profissionais, embora gostasse muito do que era discutido e vivenciado no curso. Aprendi muito, minha percepção sobre a arte erudita cresceu sensivelmente. Além do mais, pelos próprios exercícios e atividades vinculadas ao teatro desenvolvi muitas habilidades que hoje são caras em minha atuação como educador e professor universitário. Tornei-me muito mais desinibido e aprendi a falar em público e a improvisar. Aprendi a lidar com plateias relativamente grandes e não me intimidar. Desenvolvi um pensamento um pouco mais dialético, que tentava aprender os diferentes pontos de vista presentes em uma discussão ou situação. Tudo isso me serve até hoje. Mas aprendi também que o que mais me interessava não eram as questões propriamente artísticas, mas as questões sociais. Daí fiz um novo vestibular, agora para ciências sociais. Voltei a querer ser um cientista, agora um cientista social. 


\section{A FACULDADE DE CIÊNCIAS SOCIAIS E A ESPECIALIZAÇÃO EM SOCIOLOGIA URBANA}

Passei para o curso de ciência sociais na Universidade Federal do Rio de Janeiro - UFRJ e percebi que era aquilo o que eu realmente queria como profissão. Entretanto, tive dificuldades no curso por duas razões. A primeira porque me envolvi de forma significativa com o movimento estudantil universitário, o que me fez ser um aluno medíocre. A segunda porque queria ter meu próprio dinheiro e o curso na UFRJ só era oferecido de dia, me impedindo de trabalhar. Assim, depois de certo tempo larguei o curso e fiz um novo vestibular, também para ciências sociais, mas agora na Universidade Federal Fluminense - UFF, que oferecia este curso no período noturno.

$\mathrm{Na}$ UFF, me dediquei firmemente aos estudos. Das três habilitações oferecidas pelo curso (sociologia, ciência política e antropologia), fiquei mais próximo inicialmente da antropologia, da qual logo no segundo ano de faculdade fui monitor. Também consegui um estágio no setor de antropologia do Museu do Índio. Além de descortinar toda uma discussão acerca da riqueza cultural existente no Brasil, este estágio me propiciou atuar como assistente de pesquisa de antropólogos que realizavam trabalhos de campo. Em especial destaco os três meses que fiquei em campo na aldeia dos índios Fulni-ô, em Pernambuco. Foi uma experiência extremamente marcante e que me permitiu desenvolver não só habilidades de pesquisa vinculadas à observação participante e à descrição densa ${ }^{8}$, como a conhecer um outro Brasil, muito distante daquele de minha origem. Foi no Museu do Índio também que conheci Rosana Najjar, mulher com quem estou casado há trinta e cinco anos. Ela surgiu em um dia como estagiária do Setor de Arqueologia e desde então (estamos falando do ano de 1981) construímos uma vida conjunta cheia de realizações.

Todavia, minha relação com a antropologia, embora até hoje muito presente, perdeu seu protagonismo frente à sociologia, pois esta me dava muito mais proximidade com as questões sociais e políticas, que me inquietavam como cidadão. Terminei a faculdade, mas a perspectiva era continuar estudando em busca de uma vida acadêmica mais robusta. Nesta medida, ingressei no curso de especialização em Sociologia Urbana na Universidade do Estado do Rio de Janeiro - UERJ. Neste curso tive a oportunidade de atuar como assistente de pesquisa da professora Ana Maria Bianchini Baeta, em uma pesquisa sobre a

$8 \quad$ Ver Geertz (2008). 
representação social dos diretores escolares. Tal pesquisa modificou mais uma vez minhas opções acerca de meu futuro acadêmico e profissional. Descobri a Educação.

Nunca as questões educacionais haviam sido objeto de minha preocupação. Talvez até achasse que elas fossem questões menores frente a tantas outras que marcavam a vida em nosso país e no mundo. $\mathrm{Na}$ pesquisa vislumbrei o quão importantes e interessantes as questões educacionais eram e como elas estavam presentes nas reflexões de pensadores com a estatura de um Durkheim, um Bourdieu e outros. Comecei a estudar teóricos do campo educacional e passei a me sentir cada vez mais atraído por eles.

Cursando a especialização em Sociologia Urbana, um fato modificou minha vida. Um colega de turma que trabalhava como professor na Universidade Veiga de Almeida me contou que estava se mudando para o exterior e que no meio do semestre teria que deixar o emprego, prejudicando a instituição e os alunos. Assim, queria indicar meu nome para assumir suas disciplinas. Comecei então minha carreira como professor universitário, ainda cursando a especialização.

\section{TRABALHANDO EM INSTITUIÇÕES PARTICULARES DE ENSINO SUPERIOR}

Logo comecei a dar aulas de sociologia e sociologia educacional para os cursos de Pedagogia e de Letras da Veiga de Almeida. Repentinamente eu tinha diante de mim turmas com cerca de quarenta alunos, não muito mais jovens que eu, nas quais eu era o professor, isto é, alguém que deveria transmitir conhecimentos significativos de forma sistematizada e pedagogicamente competente. Não foi fácil, mas o desafio foi instigante e me permitiu aprender muito com o contato cotidiano com meus alunos. Aprendi muito a ser professor com eles. Creio até que aprendi mais com eles do que eles comigo. Paulo Freire tinha razão ao dizer que quem ensina aprende e quem aprende ensina. Trabalhei na instituição por poucos anos, até receber em casa uma carta de demissão. Estava sendo substituído por um pastor televisivo, também sociólogo, que pretensamente dava mais prestígio à instituição.

Além da Veiga de Almeida, trabalhei em algumas outras instituições particulares de ensino superior. Para ganhar um dinheiro extra e para aproveitar a oportunidade de viajar comecei a dar aulas em disciplinas de cursos de especialização da Universidade Salgado de Oliveira - UNIVERSO, que eram ministradas em pequenas cidades do interior do Brasil. Viajei para várias delas em Minas Gerais, Goiás, Pernambuco, dentre outros estados, em módulos de cerca de quinze dias. Conheci mais o Brasil e a realidade educacional brasileira. Aprendi 
também a ter muito mais desenvoltura em trabalhar com realidades diferentes e mesmo com disciplinas diferentes. Nas instituições particulares você acaba por ministrar diferentes disciplinas, sem muita conexão entre elas. Assim, além de sociologia, trabalhei com disciplinas de administração educacional, história da educação e mesmo tecnologia educacional. Embora esteja longe de ser ideal, pois compromete o aprofundamento necessário em um determinado campo científico, tal circunstância me obrigou a desenvolver muitas habilidades como professor.

Outra instituição em que trabalhei foi a Universidade Estácio de Sá. Lá ministrei aulas basicamente nos cursos de especialização, em especial nos cursos de direito, nas disciplinas de sociologia e metodologia de pesquisa. No entanto, nestes cursos praticamente eu só comparecia para dar as aulas, não havendo nenhum tipo de relação acadêmico-institucional mais forte. Estudei muito para dar as aulas e nisso cresci como professor, mas não tive nenhuma outra experiência acadêmica na Estácio que me tenha sido profissionalmente relevante.

Talvez a instituição privada de ensino superior mais importante em que trabalhei tenha sido a Faculdade Plínio Leite, pequena instituição situada em Niterói, hoje encampada pela universidade Anhanguera, algo que vem ocorrendo de forma sistemática no Brasil ${ }^{9}$. Nela tive realmente uma vivência como professor, comparecendo a reuniões de planejamento, orientando alunos e participando até da gestão administrativa como vice-chefe de departamento. Trabalhei na Plínio Leite até ingressar na UFF, em 1994.

\section{MESTRADO EM EDUCAÇÃO}

Outro acontecimento importante se deu enquanto cursava a especialização em Sociologia Urbana na UERJ. Fui procurado por um amigo que me propôs estudarmos para o concurso de ingresso em um mestrado de educação. Eu já estava disposto a tentar ingressar no mestrado, mas não de educação e sim de sociologia. Acabei, em uma escolha juvenil, por tentar fazer os dois cursos simultaneamente. Para o de sociologia, estudava sozinho, para o de educação fizemos um grupo de estudos que se dedicava à literatura educacional brasileira e então contemporânea. Acabei passando no mestrado em sociologia da UFRJ e nos em educação da UERJ e da UFF. Destes, optei pelo da UFF. O cotidiano de estudos e trabalho mostrou a impossibilidade de conciliar dois mestrados e, em uma "escolha de Sofia", de forma surpreendente, levando em consideração minha formação inicial, optei em permanecer no mestrado em educação da UFF. 
No decorrer do curso fui aluno de vários professores que me marcaram profundamente. Dentre outros, cito o professor Gaudêncio Frigotto, com seu jeito simples de explicar coisas complicadas e sua coerência e rigor acadêmico ao discutir as questões relativas ao materialismo histórico e à relação entre trabalho e educação; o professor Jésus Alvarenga Bastos, com sua experiência teóricoprática na administração educacional, fruto de seus estudos no Brasil e no exterior e de sua vivência como gestor universitário em diferentes cargos; o professor Luiz Antônio Cunha, com seu rigor e competência acadêmica que ministrou as disciplinas de Educação Brasileira, obrigatória para o curso, e de Sociologia da Educação, disciplinas estas que hoje como professor da UFF tenho a honra de ministrar; e João Batista de Alvarenga Bastos, que me introduziu à discussão acerca da relação entre democracia e educação, em especial, da gestão democrática, discussão essa que até hoje marca minhas reflexões e minha produção acadêmica.

No entanto, a professora que mais me marcou academicamente foi minha orientadora de mestrado, professora Nilda Alves. Com ela aprendi que mesmo nas discussões mais gerais acerca da sociedade e da política não devemos esquecer nunca os processos cotidianos. Assim, aprendi que não pode haver uma dicotomia muitas vezes presente no campo da educação entre os processos macrossociais e os microssociais. Uns só têm sentido se ligados organicamente aos outros. Aprendi que em toda pesquisa social é fundamental trabalhar com os sujeitos, pois a estrutura sem sujeitos é uma abstração vazia e vice-versa. Com essa perspectiva e com seus escritos expandi minha noção acerca da formação do trabalho docente e aprendi que esta formação se dá num processo complexo, a partir de diversas esferas ou, mais dialeticamente, redes (ALVES, 1992, 1998). Para pensarmos nesse processo não basta observarmos exclusivamente aquilo que acontece nos bancos das universidades. Como este próprio memorial demostra, para se refletir sobre minha formação é fundamental levar em consideração processos que passam por minha relação com meus alunos, com as instituições, com a família etc.

Logo agreguei-me ao grupo de pesquisa da Professora Nilda Alves, que na época começava uma pesquisa acerca da expansão da rede escolar pública na cidade do Rio de Janeiro. Era um grupo extremamente dinâmico que, ao mesmo tempo realizava uma "pesquisa mãe", mas que também se preocupava com a elaboração das pesquisas individuais de cada um dos seus membros. Era, assim, um espaço privilegiado de orientação e discussão coletiva acerca de nossa produção acadêmica. 
A pesquisa coletiva realizada pelo grupo concentrou-se em alguns momentos da história da cidade do Rio de Janeiro ${ }^{10}$, em especial em dois que demonstraram o intenso crescimento do número de matrículas na rede. Um deles foi o período de gestão do Prefeito Mendes de Morais (1947 - 1951), e outro a gestão do Governador Carlos Lacerda (1960 - 1965).

No primeiro, esta expansão aconteceu como resultado de uma intensa migração, particularmente de nordestinos para a cidade do Rio. A zona rural do Rio de Janeiro, particularmente Santa Cruz, Campo Grande e afins, que eram marcadas por grandes laranjais e outras plantações começaram a ter suas fazendas transformadas em loteamentos para abrigar o contingente populacional que chegava no Rio. Cada um desses loteamentos era obrigado a reservar espaços para convívio social e para a construção de uma escola ${ }^{11}$.

Cada um dos componentes do grupo ficou responsável por um aspecto desta expansão, tentando ligar esta discussão com o teor previsto para sua dissertação de mestrado. Coube a mim entrevistar professores que vivenciaram tal expansão e, consequentemente, as mudanças na forma como se organizava o trabalho docente na rede pública. Tive a honra de entrevistar cerca de oito professores que ingressaram na carreira docente no final dos anos 40 e início dos anos 50 . Trabalhei com eles a metodologia da história oral, triangulando os dados obtidos com outros decorrentes das demais metodologias usadas na pesquisa.

Era um pesquisador ainda bastante inexperiente, mas tive o apoio não só de minha orientadora, como de todo o grupo para tentar acertar mais do que errar. Aprendi muita coisa. Em especial desenvolvi a ideia de escuta sensível, que parece simples, mas precisa ser treinada e introspectada. A tendência primeira é a de nos arraigarmos a determinados temas e pressupostos da pesquisa, não escutando ou pouco escutando o que os outros dizem. A exemplo disto foi o caso das escolas rurais. Nas entrevistas, meu grande objetivo era tentar identificar as mudanças ocorridas no trabalho docente, entretanto, em todas elas os entrevistados se referiam a sua ida para as escolas rurais. Com o primeiro e o segundo entrevistados, mudei de assunto, mas no terceiro, finalmente, escutei e vi que as escolas rurais eram um fator extremamente importante, não só para a vida dos professores, como para a forma como se deu a expansão da rede de escolarização pública no período. Todos os professores que ingressavam na rede eram lotados em escolas rurais por pelo menos dois anos.

10 Vale lembrar que ela já foi Distrito Federal, Estado da Guanabara e Cidade do Rio de Janeiro.

11 Para aprofundamentos na análise da evolução urbana do Rio de Janeiro, ver Abreu (2013). 
Tal fato nos parecia algo sem sentido, pois a cidade estava, mesmo na sua periferia, deixando as atividades rurais de lado e se urbanizando. Como então explicar essa prioridade nas escolas rurais? Aprofundando a pesquisa vimos que grande parte destas escolas não desenvolviam qualquer atividade própria ao ensino rural, apesar de sua designação. $\mathrm{O}$ termo rural a elas atribuído tinha muito mais relação com o financiamento americano para a educação no Brasil que identificava nosso país como o "celeiro da América", do que com o contexto social específico no Rio de Janeiro.

\section{DOUTORADO EM EDUCAÇÃO}

Já como professor da UFF, ingressei no doutorado em educação da UFRJ, curso este que tive que abandonar dois anos depois em função de seríssimos problemas familiares. Meus dois irmãos faleceram num intervalo de menos de um ano, sendo que um deles deixou esposa e filhos pequenos e, além disso deixou de estar à frente da pequena fábrica de roupas que meu pai possuía, que entrou em falência, com muitas dívidas, que fui obrigado a saldar para não prejudicar ainda mais meu pai. Não tinha qualquer possibilidade real de levar a frente um doutorado de qualidade neste contexto, mas além de tudo que aprendi ganhei amigos que até hoje participam de minha vida acadêmica, como o Prof. Dr. Máximo Masson, o Prof. Dr. Giovani Semeraro e o Prof. Dr. Luís Dourado, colegas de turma.

Apesar disso, o pouco tempo que fiquei na UFRJ me trouxe grande crescimento. No início, tive como orientador o Professor Werner Market, pesquisando a questão do trabalho no interior da escola. Logo depois, com a saída do Professor Werner, tive a honra de ser acolhido pela Professora Maria de Lourdes Fávero, que em consenso comigo modificou radicalmente meu tema de pesquisa, pois passei a pesquisar a história da Faculdade Fluminense de Filosofia (FFF), instituição comunitária que depois de federalizada derivou não só a Faculdade de Educação da UFF, como uma série de outros institutos e escolas desta Universidade.

Apesar de não ter feito uma tese sobre o assunto, parte do pesquisado está explicitado em um alentado artigo publicado em um livro organizado pela Profa. Dra. Flávia Barros de Araújo ${ }^{12}$.

Embora não tenha conseguido terminar com êxito meu doutorado na UFRJ, nunca perdi a perspectiva de fazer um doutorado. Assim dois anos depois, realizei com sucesso a seleção para ingresso no doutorado em educação da Universidade de São Paulo (USP). Nesta instituição fui orientado pela querida 
Profa. Dra. Lisete Arelaro, que muito influenciou em minha formação como professor e pesquisador. Aprendi mais uma vez que compromisso político, rigor técnico e suavidade no trato com os outros não são coisas excludentes. A Profa. Lisete nunca abriu mão de participar de todas as discussões políticas acerca da educação e mesmo da sociedade geral, tendo sido recentemente, inclusive, candidata à Governadora de São Paulo pelo PSOL. Esta mesma professora era aquela que nas aulas que terminavam no final da tarde estendia suas discussões até cerca das $23 \mathrm{~h}$ para desespero dos vigias da USP e para deleite dos seus alunos.

No doutorado da USP, mantive contato profícuo com uma série de professores que até hoje influenciam a minha vida acadêmica, como o Prof. Dr. Romualdo Portela, a Profa. Dra. Sandra Zakia e, dentre muitos outros, o Prof. Dr. Afrânio Catani. Tive a sorte também de fazer um curso que me abriu muito os horizontes com o Prof. Dr. Licínio Lima, da Universidade do Minho. Este me possibilitou contato com uma série de autores europeus pouco trabalhados no Brasil e com questões importantes da sociologia das organizações aplicadas ao ambiente escolar ${ }^{13}$.

Quanto à minha tese de doutorado, quis trabalhar com as políticas públicas em educação levadas a cabo pelo governo Anthony Garotinho (1999 - 2002). Com o decorrer dos estudos, particularmente, com a defesa da qualificação, reduzi o espectro de minha pesquisa a uma dessas políticas, que marcaram indelevelmente a educação no Estado do Rio de Janeiro: o Programa Nova Escola - PNE.

O PNE tinha como objetivo declarado a melhoria da qualidade da educação na Rede Pública Estadual. Para tal, criava um sistema de avaliação das escolas a partir de uma prova feita de forma centralizada e de visitas às escolas para identificar como elas se organizavam administrativamente e como eram suas condições arquitetônicas. De fato, a prova centralizada passou a ser um grande referencial de avaliação e, mais que isso, de ranqueamento, pois as escolas eram distribuídas nos níveis 1 a 5. Para dar maior efetividade à avaliação, a cada um desses níveis correspondia a uma recompensa pecuniária para professores e diretores. Era, assim, um programa de cunho meritocrático que visava controlar a forma como se desenvolvia o trabalho docente. Este tipo de programa não era novo no Brasil nem no mundo, mas só chegou no Rio de Janeiro no ano 2000, depois de vários outros semelhantes serem implementados em outros estados (NAJJAR, 2015). O programa teve uma repercussão muito forte, não exatamente na melhoria da qualidade da educação da rede, mas no controle do trabalho docente nela existente. 
O PNE foi, em última instância, não um elemento eficaz na avaliação da qualidade da educação no estado, mas um poderoso programa de intervenção e gerenciamento, não só na forma como a escola era administrada, mas como os conteúdos programáticos eram escolhidos e trabalhados. Inclusive, pouco se fazia necessária a figura de um gestor externo para garantir sua efetividade, pois os próprios professores, no afã de auferirem um rendimento um pouco mais digno, vigiavam uns aos outros para que as determinações presentes no PNE se efetivassem.

Como em todo processo social, as resistências foram significativas, partindo tanto do cotidiano dos professores na escola quanto do movimento docente organizado. O Sindicato Estadual dos Profissionais da Educação do Rio de Janeiro - SEPE/RJ levaram a cabo uma série de campanhas deslegitimando as bases do Programa e brigando por sua suspensão. Nas escolas, de forma menos orgânica, muitos professores que discordavam do PNE efetivavam, em forma diferenciada e criativa, outros caminhos e focos de resistência. A tese de doutorado trata justamente da história da criação deste Programa por parte do governo Garotinho e das resistências levadas a cabo pelo Sindicato e professores. É um dos poucos trabalhos científicos que se debruçam sobre este importante programa e que traz como novidade a ideia da resistência como parte constitutiva de toda a política pública, que nunca vem a ser exatamente aquilo que é proposto por seus formuladores.

Como veremos adiante neste texto, ter elaborado esta tese, hoje publicada em livro (NAJJAR, 2015), me fez participar ativamente da luta do SEPE/RJ e dos professores, na resistência ao Programa, que só acabou, de fato, no governo Sérgio Cabral, mas que foi gradativamente se deslegitimando em função da disputa política travada. 


\section{O INGRESSO COMO PROFESSOR NA UFF}

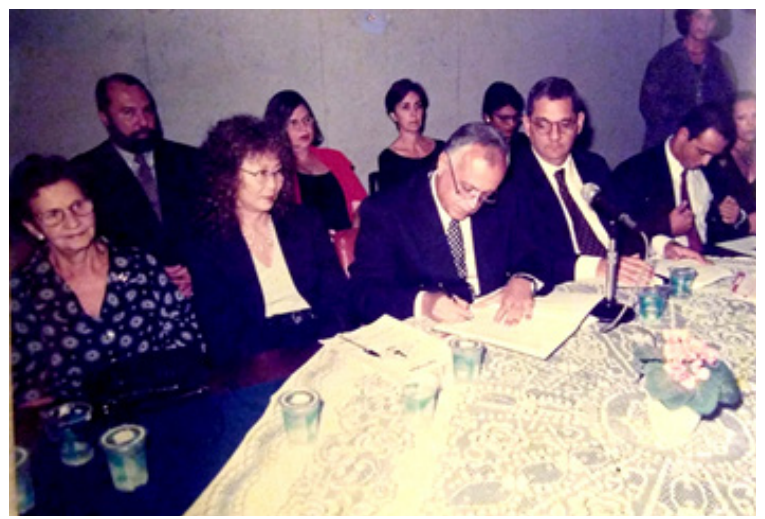

Ingressei na Faculdade de Educação da UFF - FEUFF como professor em setembro de 1994, há 25 anos. Era recém egresso do Mestrado em Educação da Instituição e continuava mantendo vínculos com ela junto ao grupo de pesquisa da Profa. Dra. Nilda Alves. Minha ligação afetiva com a instituição era muito grande, tinha um desejo enorme de participar de seu quadro docente. Vale destacar que, na época, havia a possibilidade de ingresso para professor assistente, isto é, sem a necessidade de doutorado. Foram abertos vários concursos, e dois deles me interessaram, o de Organização da Educação no Brasil e o de Análise de Dados em Pesquisa de Educação.

Os cronogramas dos dois concursos não eram conflitantes, e não havia impedimento para eu participar dos dois, sendo assim, de forma um pouco ousada, me inscrevi em ambos e comecei a estudar. Foram semanas muito duras em que me dediquei quase que exclusivamente a organizar dados, conceitos e questões sobre os pontos apresentados nos editais. Acabei passando para ambos, sendo em Análise de Dados em primeiro lugar e para OEB em segundo (para este concurso o edital oferecia duas vagas). Optei pela vaga em Análise de Dados, pois nela tinha tirado primeiro lugar. Ao longo da minha vida na UFF, entretanto, trabalhei com as duas disciplinas, até que houve uma reforma curricular e a disciplina Análise de Dados desapareceu. Desde então me dedico, em todos os semestres letivos, a ministrar a disciplina de $\mathrm{OEB}$, em uma turma ou mais, ou ministrá-la somada a alguma optativa referente ao tema de políticas públicas e gestão.

Como tomei posse em setembro, o semestre letivo já estava em curso, por isso não havia espaço para eu ministrar disciplina no campus de Niterói. Entretanto, havia um curso de Pedagogia, em caráter experimental, que funcionava em Angra dos Reis, mas que era vinculado à FEUFF. Isto é, todos os professores deste curso eram de Departamentos localizados em Niterói, e viajavam um ou 
mais dias por semana para Angra para lá ministrarem disciplinas. Este curso não se organizava em semestres letivos, mas sim em módulos (NEAP). O ano comportava de três a quatro NEAP, o que fez ser possível que em setembro eu assumisse uma turma em Angra.

Cabe notar que este curso em Angra, capitaneado pelas Professoras Nilda Alves e Regina Leite Garcia, se transformou numa referência para inúmeros cursos de pedagogia do Brasil em função da forma que era concebido e organizado. Cada NEAP possui um conjunto de disciplinas e componentes curriculares que mantinham relações orgânicas entre si, costumávamos dizer entre nós que cada NEAP tinha nome e sobrenome, isto é, tinha uma unidade que lhe dava sentido ao invés de um conjunto desconexo de disciplinas. A perspectiva era interdisciplinar, que deveria levar, inclusive, a uma forma de avaliação comum a todas as disciplinas desenvolvidas. Outro aspecto extremamente importante para o sucesso desse curso eram as reuniões entre o corpo docente, realizadas semanalmente, nas quais os professores de cada NEAP tinham o momento de reflexão conjunta sobre o que estavam fazendo, e na segunda parte da reunião a totalidade dos presentes discutia os problemas e perspectivas do curso como um todo. Tal prática era reproduzida ao final do NEAP, agora envolvendo não só os professores, mas também todo o corpo discente. Essas reflexões conjuntas eram fundamentais para que o curso tivesse uma organicidade raramente vista em outro curso de graduação.

Permaneci como docente em Angra até esta forma de organização ser substituída. O modelo de interiorização que ele representava, fruto de convênio entre a universidade e o município, que dava as condições logísticas, - não só as salas de aula mas também propiciava bolsas e alojamento para a ida dos professores para este outro município - começaram a se desgastar. Basicamente, com a troca dos governantes municipais ocorridas a cada quatro anos, crises se instalavam. Como um todo, a Universidade fez um esforço de criar polos universitários, com contratação de professores específicos para eles, e autonomia administrativa. Hoje, a UFF está em Angra com uma unidade que já oferece diversos cursos. Os novos professores que chegaram em Angra realizaram uma reforma curricular que, em grande medida, acabou com as formas novas de organização propostas pelo curso experimental.

Trabalhei no curso de Angra por vários semestres. Nele aprendi muita coisa. Por um lado, aprendi que é possível pensar diferente, extrapolando as fórmulas normais pelas quais se organizam os cursos superiores no Brasil e que isso só é possível a partir de uma cotidiana conversa entre os diferentes sujeitos envolvidos no processo. Por outro lado, aprendi quanto é difícil trabalhar em 
grupo e concretizar a tão propalada interdisciplinaridade ${ }^{14}$ no nível superior. Nós, professores universitários, temos uma formação muito individualista, que acaba por nos fazer acreditar que a disciplina que ministramos é a coisa mais importante de tudo, que merece lugar de destaque entre as outras. Exercer a humildade acadêmica é tarefa difícil, mas absolutamente necessária para a construção de uma forma nova de organizar nossa educação.

Apesar da experiência profícua em Angra, foi na FEUFF em Niterói que me construí como professor da UFF. Neste texto, de agora por diante, vou me dedicar a entender melhor como isto se deu.

\section{O ENSINO}

Como falado anteriormente, minhas aulas na graduação foram basicamente centradas na disciplina de $\mathrm{OEB}$, tendo também atuado em algumas optativas vinculadas à temática de políticas públicas e gestão. A disciplina de OEB é uma das disciplinas que marca a transição de um "ciclo básico" para o "ciclo profissional”. De fato, não existe esta denominação de ciclos e se perguntarmos a muitos professores eles vão dizer que a profissionalização e as disciplinas básicas se entrelaçam desde o início. Não nego que, por exemplo, a existência da disciplina Pesquisa e Prática Pedagógica (PPP) desde o início do curso tem o potencial de levar a uma certa superação entre teoria e prática tão presente nas licenciaturas em nosso país.

Entretanto, podemos observar que as disciplinas nos três primeiros semestres são praticamente todas oferecidas pelo Departamento de Fundamentos Educacionais, enquanto as do quinto período em diante tendem a ser oferecidas pelo outro departamento pertencente à FEUFF, Departamento de Sociedade, Educação e Conhecimento (SSE). Como o próprio nome coloca, o Departamento de Fundamentos apresenta disciplinas que podem ser consideradas como básicas tais como sociologia da educação, história da educação, antropologia da educação, psicologia da educação e outras. Já o SSE concentra as disciplinas de metodologia, didática, dentre muitas outras. A disciplina de $\mathrm{OEB}$, às vezes, é confundida com a de Política Educacional, do SFP, mas tem um caráter muito mais pragmático de entender os processos político e administrativos que se dão no interior dos sistemas de ensino.

Ao longo do tempo, acabei por optar trabalhar essa disciplina, no Curso de Pedagogia, a partir de uma discussão um pouco mais aprofundada da LDB (BRASIL, 1994), pois esta legislação dispõe sobre praticamente tudo acerca da 
forma como se organiza a Educação em nosso país. Assim, para mim, longe de uma perspectiva legalista, discutir a LDB é discutir, em grande medida, a educação brasileira e as formas como os futuros pedagogos podem lidar com ela.

Friso sempre que creio ser esta uma forma de trabalhar com o Curso de Pedagogia, pois com as outras licenciaturas acredito que outros conteúdos devem também ser priorizados. No curso de Pedagogia eles já têm mais de uma disciplina referente à história da educação no Brasil, já têm uma disciplina sobre política educacional, já têm uma disciplina específica sobre currículo. Assim, não teria sentido retrabalhar conteúdos já ministrados. Entretanto, nada disto ocorre com as outras licenciaturas, que além de $\mathrm{OEB}$, psicologia da educação e didática, tendem a não possuir outras disciplinas dedicadas a discutir de forma mais orgânica a educação.

Para além do ensino na graduação, também me dediquei por longo tempo ao ensino em diferentes cursos de especialização (pós-graduação lato sensu) existentes na FEUFF. Diferentemente de grande parte dos cursos de especialização oferecidos na UFF, todos os cursos de especialização da Faculdade de Educação são gratuitos e, em sua grande maioria, presenciais. Nesses cursos, trabalhei com disciplinas vinculadas a metodologia de pesquisa, trabalho docente, políticas públicas e gestão. Foram experiências bastante interessantes pela diversidade de temática dos cursos e de origem dos discentes.

Finalmente, depois de algum tempo como professor da UFF, ingressei no programa de pós-graduação stricto sensu em Educação. Nele tenho trabalhado, basicamente, com a disciplina, obrigatória para o mestrado, de Educação Brasileira. Embora o programa desta disciplina seja modificado de ano para ano, ele vem mantendo ao longo do tempo uma estrutura básica. O semestre letivo é dividido em duas partes, a primeira dedicada a uma recuperação histórica acerca das formas de se organizar a Educação Brasileira desde o início da colonização até o tempo presente. Nesta parte tenho como eixo algumas questões estruturantes que, a meu ver, marcam nossa história educacional, tais como, a relação públicoprivado, centralização e descentralização, e sua perspectiva excludente para a maioria da população brasileira. A segunda parte da disciplina é dividida em temáticas importantes para a educação brasileira, tais como, educação integral, educação especial, educação inclusiva, ensino profissionalizante, dentre vários outros. Esta forma de organização do curso tem tido sucesso e sido elogiada pelos estudantes.

Trabalhei também com a disciplina de Temas de Pesquisa, como a anterior obrigatória para o mestrado, que não só discute os princípios da pesquisa em educação, apresenta as principais perspectivas metodológicas utilizadas na linha de 
pesquisa que participo, mas também tenta fazer com que os alunos desenvolvam o máximo possível seus temas de pesquisa antes de um contato mais próximo com seus orientadores.

Além destas duas disciplinas, episodicamente ministro outras a partir da demanda dos alunos e do rumo que à época meus estudos estão tomando. Em especial, gosto de trabalhar com democracia e educação, tópicos especiais em políticas públicas e sociologia da educação. Trabalhar com essas disciplinas creio que areja a discussão e me obriga a estudar profundamente as temáticas abordadas.

\section{GESTÃO UNIVERSITÁRIA}

O tripé que rege a universidade brasileira é ensino, pesquisa e extensão. Um professor universitário tem que realizar atividades nestes três níveis acadêmicos. Embora, infelizmente, nem todos o façam, creio que deveríamos adicionar uma outra perna a este tripé: a gestão universitária. Na história de nossas instituições de ensino superior conseguimos fazer com que sua gestão, diferentemente de muitos países, não fosse capitaneada por administradores externos, descolados do cotidiano da instituição. $\mathrm{O}$ ensino superior público, além da existência obrigatória, como determina a LDB, dos conselhos como potenciais propiciadores da gestão democrática na instituição, todos nossos dirigentes, do reitor ao chefe de departamento, passam por consultas a comunidade. Assim são todos professores que mereceram a confiança de seus pares e dos outros segmentos (estudantes e funcionários). Este parece ser um caminho de gestão extremamente promissor que deve ser cultivado com carinho por todos nós.

Não é isso, entretanto, que hoje podemos identificar no cotidiano das instituições. Como a demanda por produtividade acadêmica é cada vez maior, e o que vale para o prestígio acadêmico é publicar em periódicos qualificados, sendo os cargos de gestão universitária cada vez mais preteridos. Identifica-se usualmente processos em que faltam candidatos aos cargos, ou que eles são preenchidos numa espécie de rodízio entre os professores o que nada tem a ver com uma ideia de gestão democrática.

Tendo este raciocínio como norte, em toda a minha vida universitária não só pesquisei sobre gestão, mas exerci cargos de gestão com empenho e prazer e este exercício, no geral, não me trouxe grande prejuízo acadêmico.

Fui chefe do departamento Sociedade, Educação e Conhecimento por dois mandatos. Este é o maior dos dois departamentos da FEUFF, contendo quase que o dobro de docentes do outro. 
Não é simples administrar um departamento grande com todos seus egos e interesses específicos. A necessidade semestral de alocação dos professores nas disciplinas é sempre uma dor de cabeça, mas nada que com muita conversa não se resolva. Talvez seja essa a característica fundamental do gestor universitário, ele tem que ser uma pessoa que converse. Nossa ascendência funcional sobre os professores, isto é, a capacidade de dar ordens que vão ser obedecidas, é bastante baixa, o que não é ruim. Assim, usa-se muito mais do convencimento do que da coerção, esta só usada em casos muito extremos.

A relação do gestor com os funcionários técnico administrativos muitas vezes apresenta dificuldades, e também com eles a conversa e o convencimento têm que estar sempre presentes. Mas o chefe de departamento, tal qual como qualquer outro gestor, não pode se dedicar exclusivamente às questões cotidianas da gestão, mas precisa ter uma perspectiva propositiva, no sentido de melhorar cada vez mais aquilo que acontece. Tem de "apagar todos os incêndios" e "matar todos os leões" diariamente, sem perder a noção de que, antes de mais nada, exerce uma função política, no sentido de ajudar a construir um futuro melhor para a instituição.

Compus, também, por oito anos, a Direção da Faculdade de Educação, sendo quatro como Vice-Diretor e quatro como Diretor, ao lado, primeiramente como Vice da Profa. Dra. Márcia Pessanha e, depois, tendo como vice o Prof. Dr. Marcos Barreto. Minha passagem por este nível de gestão alargou tremendamente meus horizontes acerca do que é a UFF e a universidade brasileira em geral. O Fórum de Diretores por nós criado para facilitar a efetivação de uma série de questões gerenciais me fez tomar contato com a realidade de todas as outras unidades da universidade, das quais era bastante distante; me fez também, de forma organizada, junto com os outros diretores, realizar negociações com a administração central de forma eficaz e, na maioria das vezes, tranquila. Note-se que as grandes questões políticas de definição de rumos da universidade nunca foram tratadas no Fórum de Diretores, pois isso seria enfraquecer a instância por excelência responsável por tais questões: o Conselho Universitário (CUV).

Participar da direção de uma unidade é um trabalho árduo, mas extremamente interessante. O Diretor é $70 \%$ do tempo um síndico do prédio, sendo assim cobrado e tendo de dar soluções desde a falta de papel higiênico nos banheiros até as falhas recorrentes de um elevador velho cuja manutenção não cabia à Direção. Como caso interessante cito a situação ocorrida uma vez em que uma quantidade considerável de carne apodreceu no Restaurante Universitário e que alguns alunos fizeram um abaixo assinado contra mim pelo ocorrido. Mais uma vez a conversa foi fundamental. Os outros $30 \%$ do tempo do Diretor, entretanto, são de grande articulação política interna à unidade, 
interna à UFF e mesmo externa à UFF, desenvolvendo seu trabalho, junto a toda a comunidade universitária, com reflexão sobre os caminhos e formas de tornar nossa universidade ainda melhor do que é. Essas reflexões conjuntas, entretanto, como não poderia ser diferente, são marcadas por grande diversidade de opiniões. Lidar com ela não é tarefe simples, mas absolutamente necessária para que uma gestão de qualidade se efetive.

Além dos cargos de gestão ligados ao Departamento e a Unidade, também participei da gestão de cursos. Primeiramente nos cursos de especialização. Nestes fui durante vários anos Coordenador do Curso de Especialização em Educação Brasileira e Movimentos Sindicais, criado, por iniciativa das Professoras Doutoras Nilda Alves e Regina Leite Garcia, em parceria com o SEPE/RJ e com o SIMPRO/ RIO. Fui também Coordenador pro tempore do Curso de Educação Especial, desta vez em função da impossibilidade de professores mais especializados assumirem.

Mais recentemente, fui eleito Coordenador do Programa de PósGraduação em Educação da UFF. A passagem por esta coordenação foi extremamente enriquecedora pois entrei em contato profundo com coisas que sabia que existiam, mas não tinha maior proximidade. Aprendi a lidar com o financiamento para pós-graduação, a preencher a tão famosa Plataforma Sucupira e a lidar com as questões referentes às bolsas junto a CAPES, CNPq e FAPERJ. É todo um novo conhecimento que só quem está imbuído da responsabilidade de dar conta dessas tarefas acaba assimilando. Além disso, temos o cotidiano do Programa no qual, dentre outras coisas, há de se cobrar prazos, lidar com reclamações de orientadores sobre orientandos e vice-versa, e das impossibilidades de realizar coisas, em função das regras administrativas, impossibilidades essas que são vistas por muitos colegas como incompetência. Isto não quer dizer que o cotidiano tenha sido por demais árduo, muito pelo contrário, o contato com professores, funcionários e alunos, no geral, é extremamente prazeroso e educativo.

Nenhum desses cargos de gestão acima apontados teria possibilidade de chegar a bom termo sem a existência dos colegiados a eles relacionados. $\mathrm{O}$ colegiado, reunindo representantes (p. ex., o Colegiado de Unidade), ou sendo composto pela totalidade dos sujeitos envolvidos (p.ex., o Colegiado da PósGraduação stricto sensu) é lugar privilegiado de reflexão qualitativa que faz com que as ideias sejam depuradas chegando ao melhor senso. Mesmo as reuniões de colegiados mais duras, com mais discussão e divergências, cumprem esse papel. Além do mais, a existência dos colegiados dá uma segurança enorme ao gestor, pois as decisões tomadas nunca são exclusivamente dele, mas são respaldadas pela 
maioria dos membros que os compõem. Reafirmo que a gestão democrática não é um elemento que tira o poder do gestor, mas que dá a este gestor mais poder e mais competência para lidar com as questões que lhe são pertinentes.

\section{A EXTENSÃO E O CONTATO COM REDES, ESCOLAS E MOVIMENTOS SOCIAIS}

Dos três elementos que compõem a tão propalada tríade universitária ensino, pesquisa e extensão -, esta última tem sido vista como a mais desprestigiada. Entretanto, em minha trajetória acadêmica ela cumpre papel importante. Tenho recorrentemente realizado tarefas extensionistas junto a escolas, redes de ensino e movimentos sociais. Tenho, também, embora de forma menos recorrente, realizado projetos que envolvem número grande de sujeitos e que, sem dúvida, possuem uma efetividade muito maior do que atividades isoladas. Em todas essas atividades, tento vencer uma tendência que identifico em grande parte das atividades extensionistas, qual seja, a ideia de que a universidade, numa perspectiva iluminista, entraria em relação com a comunidade para despejar conhecimento sobre ela, pois a concepção última seria a de que a comunidade nada sabe. Pelo contrário, em todas as minhas atividades aprendi tremendamente com o contato com o outro. Creio que só assim, respeitando e levando em consideração os saberes da comunidade o trabalho extensionista pode se fazer eficaz. Nesta medida, só creio ser possível se fazer extensão vinculada à pesquisa. Uma pode e deve ser elemento potencializador da outra. Isto tudo não é fácil de fazer, mas se não tivermos este direcionamento logo no início de nossa relação com a comunidade nunca conseguiremos que essa relação positiva entre extensão e pesquisa se efetive.

No que tange aos projetos de extensão um pouco mais alentados que participei, gostaria de citar três que muito me marcaram. O primeiro foi um projeto coordenado por mim e pela Professora Cecília Medeiros denominado PRONERA. Era um projeto oficial que tinha por objetivo associar os esforços do INCRA, dos movimentos sociais do campo (principalmente Movimento dos Trabalhadores Rurais Sem Terra - MST e Confederação Nacional dos Trabalhadores na Agricultura - CONTAG) e de universidades para o aumento da escolarização das pessoas do campo. Em especial, a nossa foi a de formar professores dos movimentos sociais para a melhoria da qualidade da alfabetização por eles realizada. Foi um projeto grande que englobou professores e alunos da UFF e professores de acampamentos e assentamentos dos movimentos sociais do campo. Além das tarefas mais gerais de coordenação, fiquei responsável pela região de Campos dos Goytacazes, que à época possuía um número razoável 
de assentamos. Junto com Prof. Dr. Marcos Barreto visitamos todos os assentamentos para mobilizar as pessoas para as atividades de formação e fizemos algumas oficinas para aqueles que, já trabalhando na área de educação, tivessem interesse.

Conheci uma realidade muito distante da minha, embora próxima geograficamente. Pensar em educação no Brasil sem esta experiência é ter uma reflexão até certo ponto incompleta do que, de fato, é a realidade do nosso país. A experiência de realizar oficinas dentro de taperas, infestadas por marimbondos, que eram usadas como escolas, mostra a pertinência da frase de Paulo Freire de que se educa até de baixo de uma árvore, mas não tenho dúvidas que as condições materiais presentes numa escola são fundamentais para que o processo educativo se efetive com mais facilidade.

Ao final do projeto realizamos um trabalho de imersão com os educadores do MST e da CONTAG. Conseguimos um alojamento para 60 educadores que permaneceram juntos por uma semana de imersão, convivendo e trocando experiências, o tempo todo, sobre educação. Foi uma vivência ímpar, na qual todos nós aprendemos e ensinamos muito. Vale destacar o embasamento teórico de muitos dos militantes, principalmente os do MST. Isto relaciona-se à forma como este movimento social lida com a educação, vista como mais uma cerca, além do latifúndio e do capitalismo, que deve ser derrubada no processo de emancipação dos trabalhadores do campo. A ideia é a de formular e de socializar entre os membros do movimento uma pedagogia que, ao contrário, se opor a suas atividades, seja uma pedagogia forjada na luta social ${ }^{15}$.

O segundo projeto extensionista que gostaria de explicitar realizou-se junto à Secretaria Municipal de Educação do Rio de Janeiro. Eu e a saudosa Profa. Dra. Sueli Camargo realizamos uma série de tratativas junto ao setor responsável pela formação de gestores e acordamos e realização de um curso de extensão de 80 horas, cujos conteúdos foram definidos tanto por eles, quanto por nós, para diretores e diretores adjuntos da rede municipal de ensino. Este projeto me parece relevante de ser mencionado por possuir algumas características interessantes. Uma delas foi sua abrangência, pois ao seu término, dele participaram cerca de 900 diretores de todas as regiões do município do Rio de Janeiro. Este número era próximo do número total de escolas da rede municipal, embora saibamos que por vezes havia mais de um diretor por escola participando. Vale apontar que a escolha por participar do curso era do diretor, não havendo qualquer tipo de obrigatoriedade. Parecia que os diretores queriam conversar, vencendo um pouco a solidão que muitas vezes marca este cargo. 
As aulas foram ministradas em diversos locais do município, fazendo com que os diretores não tivessem que vencer grandes distâncias para delas participar. A metodologia utilizada era, o máximo possível, dialógica. Isto é, longe de grandes exposições por parte dos professores, a ideia era a de que os diretores conversassem e desta conversa que exigia uma reflexão um pouco mais aprofundada sobre suas experiências, os tópicos do curso fossem sendo construídos. Na avaliação final do curso, esta foi uma das características mais destacadas dos professores, inclusive contrapondo-as a outras atividades de extensão que participaram.

Finalmente, uma estratégia do curso muito bem-sucedida foi o trabalho final que os cursistas tinham que fazer. Individualmente ou em dupla, com a orientação de um professor, eles tinham que fazer uma espécie de artigo ou relato, de cerca de quinze páginas, sobre sua experiência como diretor na escola. Claro que nem todos conseguiram. Entre os que conseguiram, alguns fizeram só por fazer, mas a grande maioria se empenhou profundamente. Criamos então um $\mathrm{CD}$ com todos esses relatos e distribuímos para todos os diretores e suas escolas, fazendo com que tivessem um banco de experiências extremamente interessante e que também se sentissem ainda mais autores de uma reflexão legítima sobre sua realidade.

O terceiro e último programa que gostaria de relatar ocorreu junto à Secretaria Municipal de Educação de Nova Iguaçu, quando da primeira gestão de Lindbergh Farias como prefeito (2009 - 2013). A Secretaria Municipal de Educação já havia feito convênio amplo com o Instituto Paulo Freire - IPF e vinha realizando uma série de trabalhos extremamente interessantes frente, principalmente, à forma como era concebida e executada a gestão educacional no município. Entretanto, não havia qualquer tipo de atividade destinada à formação de professores. Eu e a Profa. Dra. Mônica Silvestri, em conversa com membros dessa Secretaria, elaboramos um vasto programa de formação centrado basicamente nas questões de ludicidade, brinquedos e educação; português; alfabetização e letramento; e matemática.

Além desses e outros Programas de Extensão que eu participei, realizei inúmeras atividades extensionistas mais pontuais. Fui convidado e aceitei participar de dezenas de atividades de abertura de semestre letivo de diferentes redes do estado do Rio de Janeiro, bem como de suas Semanas Pedagógicas. Nessas ocasiões sou procurado por representantes de escolas dessas redes que querem que eu reproduza as discussões travadas ou trave alguma outra discussão específica para seus professores. É um trabalho extremamente desgastante, porque às vezes viajo três horas para chegar ao município onde a escola está localizada, converso uma hora com os professores e viajo outras três horas de volta ao meu município. 
Parece insano, mas a felicidade dos professores de municípios distantes ao receberem em sua "casa" um professor da UFF para conversar com eles compensa o esforço. Sem dúvida, a efetividade das discussões é muito menor do que a existente em um programa de extensão, mas, mesmo assim, creio que este tipo de atividade ajude a despertar o interesse tanto pela melhoria da Educação, como pela melhoria da sua formação acadêmica. Vários professores que conheci nessas atividades voltei a ver em cursos e seminários na UFF. Essas atividades mais pontuais, entretanto, ganham maior potência quando levadas a cabo por entidades ou movimentos sociais. Cito o périplo que fiz por praticamente todos os municípios do estado do Rio de Janeiro levado pelo SEPE/RJ para discutir o Programa Nova Escola. Cito, também, a parceria que venho construindo junto ao Grupo de Apoio e Fortalecimento dos Conselhos Escolares do Rio de Janeiro GAFCE/RJ, que me tem feito percorrer diversos municípios discutindo questões relacionadas à gestão democrática nas escolas e ao papel destes conselhos. Quanto à relação com o GAFCE/RJ vale lembrar que organizamos um curso para sessenta conselheiros escolares com duração de seis meses, que reuniu pessoas de cerca de quarenta diferentes municípios e que derivou, a partir dos trabalhos finas dos alunos, um e-book publicado em parceria com o Ministério Público Estadual do Rio de Janeiro.

\section{O NÚCLEO DE ESTUDOS E PESQUISAS EM GESTÃO E POLÍTICAS PÚBLICAS EM EDUCAÇÃO - NUGEPPE}

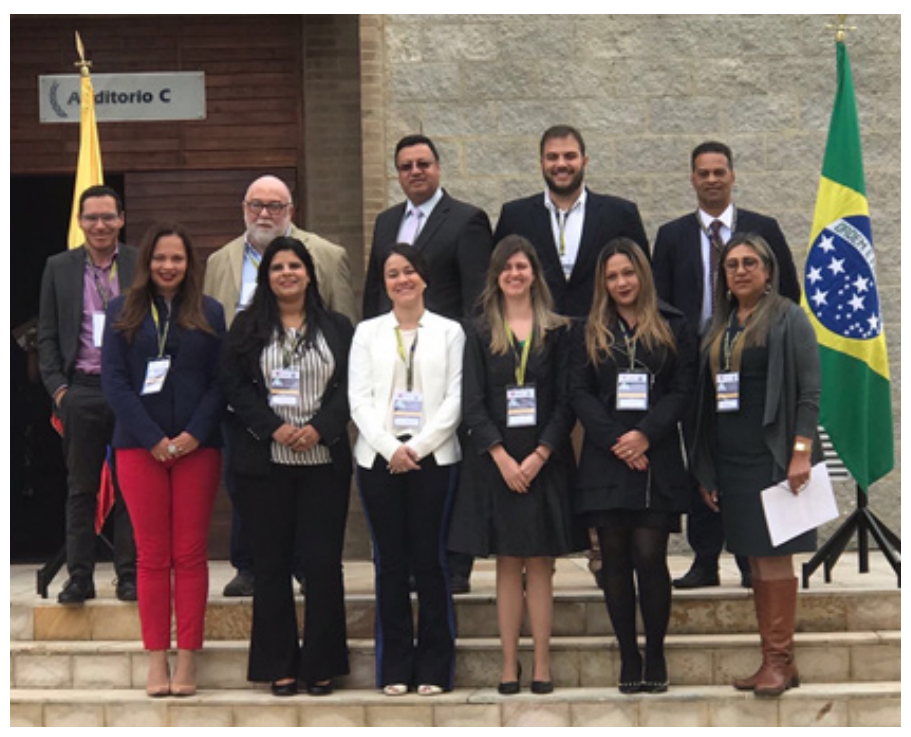


Talvez uma das realizações acadêmicas que mais me orgulhe seja a criação do Núcleo de Estudos e Pesquisas em Gestão e Políticas Públicas em Educação (NUGEPPE).

Há cerca de quinze anos, começa a proliferar na FEUFF uma forma de organização acadêmica que já existia, mas que era relativamente restrita a poucos casos: os grupos ou núcleos de pesquisa e extensão. Estes grupos primeiro tiveram uma existência na qual não havia regras mais claras, mas com o crescimento do número de grupos, o colegiado de unidade da FEUFF elaborou uma resolução, muito pouco burocrática, para organizar a forma que esses grupos deveriam ter. Mas o que são esses grupos? Eles são uma forma para além das estruturas universitárias clássicas (departamentos, cursos etc.) de organização acadêmica, superando dicotomias históricas, tais como graduação versus pós-graduação ou pesquisa versus extensão. São grupos cujo coordenador é necessariamente um professor da FEUFF e seus participantes são professores da instituição, alunos de graduação e de pós-graduação e membros externos à instituição, sejam de outras IES ou da Educação Básica. Eles realizam com maior ou menor ênfase, dependendo de cada grupo, pesquisa e extensão, sendo hoje parte deles referências em suas áreas temáticas.

O NUGEPPE não é diferente desses grupos. Ele nasceu há cerca de 10 anos, reunindo dois professores, eu e a Profa. Dra. Sueli Camargo, e três alunos, sendo dois de pós-graduação e um de graduação, em torno de uma pesquisa/ extensão em parceria com a ONU-HABITAT, a Petrobras e quatro outros grupos de pesquisa e extensão de outras unidades da UFF (Urbanismo, Economia, Geologia e Medicina Social). Nossa pesquisa comum era o monitoramento das questões socioambientais dos onze municípios abarcados pelos COMPERJ. O grupo logo começou a crescer incorporando outros professores, meus orientandos de mestrado e doutorado e pessoas externas à instituição que queriam recomeçar sua vida acadêmica em um grupo de pesquisa.

Hoje, o grupo possui cerca de 30 membros e uma atuação acadêmica de peso. Ao longo de nossa pequena história, além das várias teses, dissertações e artigos acadêmicos, elaboramos três livros com pesquisas individuais de alunos e professores e um livro com uma pesquisa coletiva realizada acerca da temática dos Planos Municipais de Educação do Estado do Rio de Janeiro ${ }^{16}$. Realizamos viagens nacionais e internacionais para participarmos de congressos e seminários acadêmicos, participamos da organização, principalmente junto a ANPAE e ANFOPE, de seminários estaduais, regionais e mesmo nacionais, sendo hoje um grupo respeitado por muitos pesquisadores no Brasil. 
O NUGEPPE tem se constituído como lugar privilegiado de formação para todos os que dele participam. Todos os textos realizados pelos seus membros são discutidos coletivamente, num exercício de humildade acadêmica extremamente enriquecedor. Aprender a escutar críticas sobre seu texto sem leválas, de forma alguma, para o nível pessoal, não é fácil. Alguns não conseguiram e saíram do grupo, mas todos aqueles que permaneceram admitem ser esta atividade uma das mais interessantes e ricas do NUGEPPE.

É curioso, mas ao mesmo tempo encantador, ver um aluno no final da graduação ou do início do mestrado tecendo críticas pertinentes, e algumas vezes ácidas, sobre o trabalho de um doutor ou doutorando. Todos têm voz, todos criticam, e todos são criticados, tal como tem que ser o meio acadêmico. Nesse processo de crítica e autocrítica as pessoas crescem. Posso ter como exemplo e só este darei para não ser exaustivo e já assumindo que não vou citar nenhum outro membro, deixando de fora todo o resto do grupo, o caso do Prof. Dr. Marcelo Mocarzel, um aluno brilhante que estava presente, como mestrando, nas origens do grupo e que hoje não só é doutor, como acaba de fazer seu estágio pós doutoral no NUGEPPE e de ingressar no corpo docente do Programa de Pós Graduação Stricto Sensu da Universidade Católica de Petrópolis - UCP. Claro que não foi o NUGEPPE o único responsável por isso, mas, sem dúvida, ele teve uma participação efetiva na consolidação desta trajetória de sucesso.

O NUGEPPE também vem tendo um papel importante na consolidação de um convênio com uma universidade colombiana. Em 2012, depois de duas viagens acadêmicas a Bogotá, firmamos um convênio com a Universidad Militar Nueva Granada (UMNG). A UFF possui diversos convênios com universidades de todo o mundo, mas parte considerável deles "não saem do papel", isto é, não se transformam em ações acadêmicas de fato. Entretanto, sendo responsável por este convênio e também coordenador do NUGEPPE, articulei um plano de trabalho que se mostrou bem efetivo.

Por sete anos consecutivos, temos realizado missões acadêmicas que permitem a troca de experiências e saberes entre pesquisadores das universidades conveniadas dos dois países. No primeiro ano, vieram dois professores e cinco alunos do Programa de Pós-Graduação em Educação da UMNG participar de atividades acadêmicas na UFF. No ano seguinte, o fluxo se deu em direção contrária, indo o mesmo número de professores e de pós-graduandos da UFF, em especial do NUGEPPE, visitar a universidade colombiana. Este intercâmbio ocorreu até o ano passado, com o apoio da CAPES, quando dez alunos de nossos cursos de Mestrado e Doutorado em Educação foram à Colômbia. 
Este convênio também derivou na publicação de três livros (dois no Brasil e um na Colômbia) que reuniram trabalhos de pesquisadores dos dois países. Em artigo recentemente publicado ${ }^{17}$, eu e os Professores Dr. Pablo Bispo dos Santos, Dr. Marcelo Mocarzel e Dra. Karine Morgan narramos como se deram as bases desse convênio, pensando a partir da lógica das epistemologias do Sul de Boaventura de Sousa Santos.

\section{A PARTICIPAÇÃO EM SOCIEDADES CIENTÍFICAS}

Outra atividade a que venho me dedicando é a participação nas associações científicas mais importantes do campo da Educação. Venho participando ativamente da ANPAE, tanto em nível local, quanto nacional. Fui por duas vezes Diretor Estadual do Rio de Janeiro e atualmente cumpro mandato de Vice-Presidente Sudeste. No exercício destes cargos, fui Coordenador Geral de mais de um Seminário Estadual e de um Seminário Regional desta instituição.

Participo também da ANFOPE, na qual fui, por duas gestões, Diretor Sudeste e atualmente faço parte da Direção Nacional, com o cargo de Tesoureiro. Atuei como Coordenador Geral de dois Seminários Regionais e participei ativamente da coordenação de um seminário nacional.

Motivo de grande orgulho foi o de ajudar a trazer para a UFF, no ano passado, a 39 $9^{\text {a }}$ Reunião da ANPEd. Como Presidente da Comissão Local, fui responsável por grande parte da logística para que este importante congresso ocorresse. Infelizmente, próximo à data do evento, minha doença fez com que eu tivesse que me afastar de grande parte de minhas atividades, inclusive da Comissão Local.

A participação em todas estas instituições foi fundamental para que eu tivesse uma percepção mais abrangente do campo educacional de todo o Brasil e criasse laços de trabalho e de companheirismo com intelectuais de diversas universidades brasileiras.

\section{A PARTICIPAÇÃO EM FÓRUNS E CONSELHOS}

Outra atividade acadêmica que vem marcando minha trajetória é a participação em conselhos e fóruns em Educação. Por vários mandatos atuei como conselheiro do Conselho Municipal de Educação de Niterói (CMEN). Nele, além das atividades administrativas de autorização de funcionamento das escolas de educação infantil de Niterói, participei, também, de uma série 
de comissões voltadas para a elaboração de resoluções sobre a organização do sistema de ensino de Niterói. Assim, por exemplo, participei da elaboração de um novo regimento para as escolas da rede pública de Niterói e da resolução que regia a oferta de atendimento educacional especializado para os alunos com deficiência, transtornos globais ou superdotação de todas as escolas do Sistema Municipal de Ensino.

Como Conselheiro Municipal, participei também, da organização do congresso municipal de educação que elaborou o Plano Municipal de Educação vigente.

Fui também membro e participante da Coordenação Colegiada do Fórum Estadual de Educação do Rio de Janeiro (FEERJ). Este Fórum, além de outras atividades referentes ao acompanhamento das políticas públicas em educação do estado do Rio de Janeiro, cobrou exaustivamente a Secretaria de Educação para que realizasse um Congresso Estadual de Educação (Coed) para a adaptação do Plano Estadual de Educação ao novo Plano Nacional de Educação. Quando este congresso se realizou, participei de sua equipe de coordenação.

Mais recentemente, há poucos meses, tomei posse como conselheiro do Conselho Estadual de Educação, órgão fundamental para o acompanhamento e proposição de políticas públicas de educação no Rio de Janeiro, presidido atualmente pela Profa. Dra. Malvina Tuttman, tendo sido indicado pela Comissão de Educação da Assembleia Legislativa do Estado do Rio de Janeiro, mais especificamente pelo deputado Prof. Dr. Waldeck Carneiro. Pelo pouco tempo de participação, ainda pouco contribuí para suas discussões e tarefas, embora já claramente identifique o quanto posso crescer com esta participação e que, potencialmente, tenho todas as condições de colaborar para a as atividades do órgão.

\section{REFERÊNCIAS}

ABREU, Maurício de A. Evolução urbana do Rio de Janeiro. Rio de Janeiro: Instituto Pereira Passos, 2013.

ALVES, Nilda. Trajetórias e redes na formação de professores. Rio de Janeiro: DP\&A, 1998.

ALVES, Nilda (org.). Formação de professores: pensar e fazer. São Paulo: Cortez, 1992. 
BAUDELOT, C.; ESTABLET, R. L'École Capitaliste en France. Paris: Librairie François Maspero, 1971.

BOURDIEU, P.; PASSERON, J. C. A reprodução: elementos para uma teoria do sistema de ensino. $6^{a}$ ed. Petrópolis: Vozes, 2013.

CALDARD, Roseli Salete. Pedagogia do movimento Sem Terra. São Paulo: Expressão Popular, 2004.

DOURADO, Luiz Fernandes. Estado, educação e democracia no Brasil: retrocessos e resistências. Educ. Soc., v. 40, 2019, p. 1-24.

FAZENDA, Ivani. Interdisciplinaridade: história, teoria e pesquisa. Campinas, SP: Papirus, 1994.

FREIRE, Paulo. Professora sim, tia não: cartas a quem ousa ensinar. São Paulo: Olho D’água, 1997.

GEERTZ, Clifford. A interpretação das culturas. Rio de Janeiro: LTC, 2008.

GONÇALVES, Eva Patrícia Duarte. A Escola e a Família, uma parceria ou uma simples aproximação? Uma análise comparada de políticas, estratégias, práticas e resultados. Tese de Doutoramento em Sociologia. Instituto Universitário de Lisboa. Escola de Sociologia e Políticas Públicas. Lisboa, 2015.

LIMA, Licínio. A escola como organização educativa: uma abordagem sociológica. São Pulo: Cortez, 2001.

MOCARZEL, Marcelo, NAJJAR, Jorge; SANTOS, Pablo Bispo dos; MORGAN, Karine. A internacionalização da pós-graduação na América Latina: do Sul geográfico às epistemologias do Sul. Revista Educação e Cultura Contemporânea, v. 16, n. 46, 2019, p. 198-219.

NAJJAR, Jorge. A disputa pela qualidade da escola: uma análise do Programa Nova Escola do estado do Rio de Janeiro. Niterói: EDUFF, 2015.

NAJJAR, Jorge. As origens da UFF e a formação de professores: a Faculdade Fluminense de Filosofia. In: ARAÚJO, F. M. B. (org.). Formação de professores: múltiplos olhares. Niterói: EDUFF, 2015b. 
OSMAN, Samira Adel. Imigração Árabe no Brasil: história de vida de libaneses muçulmanos e cristãos. São Paulo: Xamã, 2011.

SGUISSARDI, Valdemar. Modelo de expansão da educação superior no Brasil: predomínio privado/mercantil e desafios para a regulação e a formação universitária. Educ. Soc., v. 29, n. 105, 2008, p. 991-1022.

SILVA, Wilton Carlos Lima. Saber se inventar: o memorial acadêmico na encruzilhada da autobiografia e do egodocumento. MÉTIS: história \& cultura, v. 15, n. 30, p. $44-67$, jul./dez. 2016. 